\title{
Mi a függvény? -középiskolásoknak tartott foglalkozás tapasztalatai
}

\section{What is the Function? - Experiences of an Occasion among the Secondary School Students}

\author{
GY. SZANYI \\ Debreceni Egyetem, Műszaki Kar, Műszaki Alaptárgyi Tanszék, szanyi.gyongyi@eng.unideb.hu
}

\begin{abstract}
Absztrakt. Az EFOP-3.6.1-16-2016-0002200022 „Debrecen Venture Catapult Program” keretében foglalkozást tartottunk középiskolás korosztálynak többek között abból a célból, hogy egy olyan matematikai fogalmat alakítsunk, mely nemcsak a természettudományok, hanem a müszaki tudományok müvelésében is kiemelkedô fontossággal bír. Számos müszaki probléma megoldásához szükséges, hogy a tanulók birtokolják a függvényfogalom tartalmi jelentését, azaz olyan fogalomképzettel rendelkezzenek, mely kölcsönös kapcsolatban van annak definíciójával, továbbá tudjanak váltani a függvény különböző reprezentációi között. A kidolgozott foglalkozás a mindennapi életben, valamint a müszaki területeken is megjelenő kapcsolatok vizsgálatával alakítja a függvényfogalmat egyéni és kooperatív tanulási módszerrel.
\end{abstract}

Abstract. In the frame of the project EFOP-3.6.1-16-2016-00022 "Debrecen Venture Catapult Program" it was held an occasion among secondary school students the aim of which was formation of that concept which is very important in the engineering area. In many cases in order to solve problems necessary that students have an "ideal" function concept image (the image is interrelated with the notion of the concept) and they can change between different representations of the function. In our paper we will show the experiences of the occasion in which was formed the function concept by investigation of several relationships from the everyday life and engineering area with the help of individual and cooperative learning method.

\section{Bevezetés}

A függvény fogalmának ismerete, megértése és alkalmazása nem csak a matematika, hanem - többek között - a műszaki tudományok számos területének művelése szempontjából alapvető fontosságú. Emiatt is lényeges, hogy a tanulóknál az iskolai matematika tanulás során olyan fogalomképzet alakuljon ki a függvényről, melyre a későbbiekben építhető a felsőfokú matematika tananyaga.

Számos kutatás számol be arról, hogy az általános vagy a középiskola befejezése előtt álló, sőt, egyetemet kezdett tanulók „elveszettek” a függvények világában (Vinner, 1983, Szanyi, 2015, 2017b). A tanulók úgy gondolnak a függvényre, mely mindenképpen leírható képlettel (algebrai formulával) vagy reprezentálható grafikonnal (Sierpinska, 1992, Clement, 2001). Ennek oka abban is keresendő, hogy az iskolai oktatásban túlnyomó részt csak a képlettel leírható valós értékű függvények kerülnek 
tárgyalásra. Viszont ennek következménye lehet, hogy a fogalom tartalmi jelentése annak kialakítási folyamatában „háttérbe” szorul. Skemp (2005) szerint a tanulók életkori sajátosságának megfelelően tisztázni kell a definícióban (így a függvény definíciójában is) szereplő elemek jelentését és jelentőségét, valamint tudatosítani kell a szavak köznapi jelentésével való kapcsolatot.

Jelen tanulmányban bemutatásra kerülő foglalkozás elsődleges célja a fogalom definíciójában szereplő elemek jelentésének tisztázása olyan kapcsolatok vizsgálatával, melyek rendelkeznek a fogalmat alkotó közös tulajdonságokkal. Másrészt, a bemutatandó példák motivációs eszközként is szolgálnak arra vonatkozóan, hogy a függvény fogalmának alkalmazása a mindennapi és a műszaki életben is fontos, hiszen „ha elegendően gazdag tapasztalati anyagot nyújtunk a gyerekeknek, akkor a függvény fogalmát éppoly hatásosan el tudják sajátítani, mint a változó vagy a szám fogalmát." (Dienes, 2015, 157. old.). A foglalkozás továbbá egyéni és csoportmunka segítségével célozta meg azt, hogy a tanulók "eljussanak" a függvényfogalomig és fejlessze a szóbeli kifejezőképességüket is.

\section{A függvényfogalom alakításának didaktikai aspektusai}

A függvény a matematika egyik alapfogalma, melynek sokféle definíciója és reprezentációja ismert. Megértése emiatt is jelenthet nehézséget a tanulóknak. Vinner és Dreyfus tanulmányában olvashatjuk, például a következő definíciót:

"A függvény két halmaz közötti olyan megfeleltetés, mely az egyik halmaz minden eleméhez pontosan egy elemet rendel a másik halmazból." (1989, 357. old.)

Sajka (2003) szerint a tanulók nehézségeit a függvényfogalom megértésében nemcsak annak sokféle definíciója és reprezentációja, hanem kettős "természete" is okozhatja, mivel az valójában két, alapvetően különböző módon értelmezhető: strukturálisan - mint egy objektum és operatívan - mint egy folyamat. Ezeknek a módoknak pedig koherens egységnek kell lenniük (Sfard, 1991). Ennek ellenére a tanulók legtöbbször objektumként értelmezik a függvény fogalmát, mely mindenképp reprezentálható képlettel. A fogalom operatív értelmezése ("input - transzformáció-output"), mely a fogalom létrejöttéhez vezet, így elmaradhat. Ezzel együtt a fogalmat alkotó elemek - alaphalmaz, képhalmaz, kapcsolat, értelmezési tartomány, értékkészlet, hozzárendelési szabály - tartalmi jelentésének megértése is problémát jelenthet a tanulóknak. Viszont ezeknek az elemeknek az alapos ismerete és megértése elengedhetetlen a műszaki életben gyakorta megjelenő vektorértékű $\left(\mathbb{R} \rightarrow \mathbb{R}^{2}\right.$ típusú) függvényekkel leírható kapcsolatok (például az eldobott test helyvektor-idő függvénye) felismeréséhez és megértéséhez.

Piaget (1955, idézi Dienes, 2015) hangsúlyozza, hogy egy fogalom elsajátításának hosszú folyamatában szükséges, hogy a tanulók játszadozzanak a fogalom alkotóelemeivel (megfelelő időben és az adott korosztályban megfelelő játékokkal), induktív úton fedezzék fel a fogalmat, így annak alkotóelemeit is. A felfedeztető tanulásra való motiválást valós életből vett problémákon keresztül célszerű vezetni úgy, hogy a tanulók érzékeljék és verbalizálják a változásokat, felismerjék a változók közötti kapcsolatot (Sierpinska, 1992). A változások érzékelésének és az azok közötti összefüggések felismerésének, továbbá a kapcsolat képlettel történő reprezentálásának képessége a műszaki területek művelése szempontjából is nagy jelentőséggel bír (Selden \& Selden, 1992). 
Mindezek mellett a fogalom megértésének fontos aspektusa a többféle reprezentációja alkalmazásának képessége és a szükséges jellemzők átemelése egyik reprezentációs módból a másikba (Lin \& Cooney, 2001, idézi Areti et al, 2015, 440. old.), mivel ez növeli a problémamegoldás hatékonyságát is (Ambrus, 2004; Duval, 2002). A megismertetéssel együtt arra is törekednünk kell, hogy a tanulók a különböző reprezentációk között mozogva meglássák az azok között lévő kapcsolatot. Ha a fogalom kialakítása során ez nem valósul meg, akkor ezek a reprezentációk egymástól izoláltan épülnek be ismereteikbe (Thompson, 1994) és nem tudják azokat a későbbiekben összekapcsolni.

A következőkben bemutatandó foglalkozás elsődleges célja a függvény alkotóelemeinek (változók, kapcsolatok, szabályok) és magának a függvényfogalomnak a felfedezése és megértése, illetve az egyik reprezentációról egy másikra való áttérés, a szóbeli kifejezőképesség fejlesztése egyéni és csoportmunka segítségével. A csoportmunka a mérnöki életben is nagyon fontos munkaforma, mely a kapcsolatteremtés, az együttműködésre való képesség, a lényeglátás és kreativitás, az önálló vélemény kialakításának kompetenciáit erősíti (Tuke, Oppe, Dávid, 2011).

A fejlesztő foglalkozással a következő kérdésekre keressük a választ:

1. Képesek-e a 9. osztályos tanulók a kapcsolatot megadó egyik reprezentációs módról áttérni egy másik, releváns reprezentációs módra, és leginkább melyik lehetséges reprezentációs módot preferálják a tanulók?

2. Mi jellemzi az adott korosztályban a tanulók függvényfogalom-képzetét?

\section{A függvényfogalom alakítását megcélzó foglalkozás és annak tapasztalatai}

\subsection{Előzmények és módszerek}

A tanítási kísérletünkben egy magyarországi gimnázium 12, nem speciális matematika tagozatos, 9. osztályos tanulója vett részt, akik heti 4 órában tanulják a matematikát. A foglalkozásra 2018 decemberében került sor egy 45 perces tanóra keretében. A tanulóknál a függvényfogalom előkészítése a kerettantervnek megfelelően már alsó osztályban elkezdődött, a fogalom definíciójának megadása pedig 7. osztályban megtörtént és alakítása 8. osztályban tovább folytatódott.

A foglalkozás során a tanulók egyénileg és csoportokban is dolgoztak. A csoportmunka lehetőséget ad arra, hogy a tanulók megosszák eredményeiket, diszkussziót folytassanak azokról és közös döntést hozzanak a kérdés megválaszolására. A tanulók számára nem volt ismeretlen ez a munkaforma. A diákok 3 fős csoportokban dolgoztak. A foglalkozásról videó felvétel, fényképek készültek, illetve a tanulók munkáját is összegyűjtöttük. A foglalkozást a csoport matematikatanára tartotta a mi óratervünk alapján.

\subsection{A foglalkozás menete és tapasztalatai}

\subsubsection{A kapcsolatok (relációk) különböző reprezentációi alkalmazhatóságának felismerése}


A foglalkozás kezdetén a cél a halmazok elemei közötti kapcsolat különböző megadási módjainak felelevenítése volt. A különböző megadási módok (reprezentációk), illetve az áttérés egyik reprezentációról a másikra fontos szerepet tölt be az együttváltozó mennyiségek közötti függvénykapcsolatok felismerésében.

Arra a kérdésre, „... milyen módon tudunk megadni két halmaz elemei között hozzárendelést (kapcsolatot)?" a tanulók egy konkrét példa elhangzásáig nem tudtak választ adni. Miután értelmeztük a kérdést a természetes számok halmaza és a páros számok halmaza közötti kapcsolattal, az első mód, amit a halmazok közötti kapcsolat megadására hoztak a tanulók, a nyíldiagram volt. Nem meglepő, hiszen a függvény fogalmának 7. osztályban történő bevezetésekor leggyakrabban ezt a reprezentációs módot preferálják a halmazok közötti kapcsolat megadására a tankönyvek, és valószínűsíthető, hogy így a tanítási folyamatba is ez épül be elsősorban. A többi reprezentációs mód (képlet, grafikon, táblázat) csak azután jelent meg a tanulók válaszaiban, miután a példaként hozott kapcsolatot összefüggésbe hoztuk a függvény fogalmával. Jól érzékelhető volt mindezekből a válaszokból, hogy a tanulók ezeket a reprezentációs módokat a függvény fogalmához kapcsolják, melynek hatása a függvényfogalomról kialakult képzetükre az óra további részében szembetűnően megmutatkozott.

Miután a halmazok elemei közötti kapcsolatok reprezentációs módjait felelevenítettük a tanulók különböző színű kártyákat kaptak, az előre elkészített 4 darab kapcsolat közül valamelyiket. Az egyes kártyákon a különböző kapcsolatok különböző módon voltak reprezentálva.

\begin{tabular}{|c|c|c|}
\hline $\begin{array}{l}\text { A feladatkártya } \\
\text { „neve” }\end{array}$ & A kapcsolat & $\begin{array}{l}\text { A kapcsolat } \\
\text { reprezentációja }\end{array}$ \\
\hline „Füzetek” & $\begin{array}{l}\text { A vásárolt füzetek számához hozzárendeltük a } \\
\text { fizetett összeget. }\end{array}$ & táblázattal \\
\hline „Hónapok” & $\begin{array}{l}\text { A magyar ABC betűihez hozzárendeltük az adott } \\
\text { betűvel kezdődő hónapjait az évnek. }\end{array}$ & $\begin{array}{l}\text { szöveges utasítással } \\
\text { (verbálisan) }\end{array}$ \\
\hline „Mozgás” & $\begin{array}{l}\text { Egy gépkocsi } 4 \text { órát volt úton. Ez alatt az idő alatt a } \\
\text { gépkocsi által megtett út és az eltelt idő közötti } \\
\text { kapcsolatot grafikonnal adtuk meg. }\end{array}$ & grafikonnal \\
\hline „Számok” & $x \mapsto\left\{\begin{array}{rc}2 x-3, & h a 0 \leq x \leq 5 \\
3, & \text { ha } 5 \leq x\end{array}\right.$ & képlettel \\
\hline
\end{tabular}

A feladat célja, hogy a tanulók meg tudják nevezni azokat a halmazokat, melyek elemei közötti kapcsolatot reprezentáltuk, továbbá váltsanak a különböző reprezentációs lehetőségek között. Kb. 6 percig a tanulók önállóan dolgoztak, majd az egyforma színű kártyával rendelkező tanulók csoportban folytatták a munkát. Négy 3 fős csoport alakult ki. A csoportoknak az volt a feladata, hogy csoport tagjai ellenőrizzék egymás munkáit, majd beszéljék meg, hogy helyesen dolgoztak-e mindannyian, ha van hiba, akkor az kinél és milyen formában jelentkezett, a hibákat javítsák. (A tanár annak a csoportnak, amelyik nem boldogult a feladattal rávezető kérdésekkel segített.) 
A tanulók megvitatták egymás válaszát, a hibásnak vélt válaszokat más színű tollal javították. Figyelve a tanulók munkáját arra lehetett következtetni, hogy a tanulóknak nehézséget okozott, hogy a különböző reprezentációs módok közül kiválasszák azt/azokat, mely(ek) egyértelműen meghatározzák az adott kapcsolatot. Ezek a problémák a „Mozgás” és a „Számok” kártyák esetében jelentkeztek: a halmazok, melyek között kapcsolatot teremtettünk, végtelen sok elemből álltak. Ekkor olyan egyéb reprezentációs módot is használtak a tanulók, ami nem határozta meg egyértelműen a kapcsolatot. Ennek oka abban rejlett, hogy a tanulók a két halmaz elemei közül, csak az egész számokat emelték ki (1. ábra). (Személyes tapasztalatunk, hogy az egyetemet kezdett hallgatók is a valós számok részhalmazaival végzett munka során legtöbbször a halmaz elemeiből csak az egész számokkal dolgoznak.)
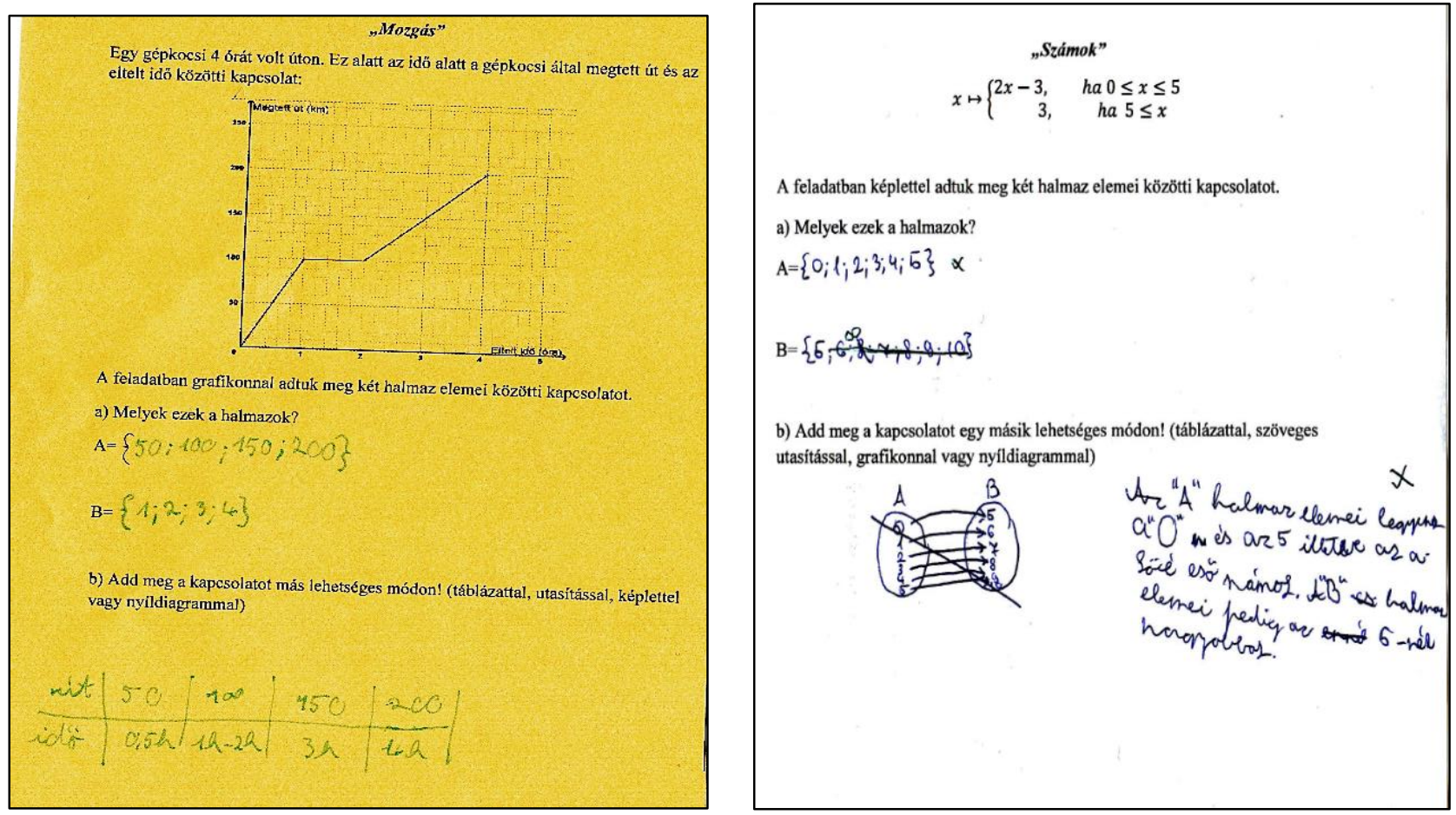

1. ábra

Mindezek okait a következőkben látjuk: a tanulók a kapcsolatok megadási módjainál nem veszik figyelembe, hogy a reprezentáció egyértelműen meg kell, hogy határozza a kapcsolatot. A kapcsolat táblázattal való megadását a függvénygrafikon ábrázolásához használt értéktáblázathoz kapcsolják. Azaz úgy vélik, hogy ha a halmazok néhány együttváltozó mennyiségét táblázattal reprezentáljuk, az már egyértelműen meghatározza a kapcsolatot.

Ezt a problémát Sierpinska (1992) azzal magyarázza, hogy a tanulók ismereteibe a különböző reprezentációs módok izoláltan épülnek be és gyakran a függvénnyel azonosítják azokat. Ez a hibás fogalmi képzet a vizsgált tanulóknál is megmutatkozott: a „Mozgás” és a „Számok” feladatok esetében az alap- és képhalmazból csak néhány összetartozó elemet ragadtak ki és azt reprezentálták táblázattal vagy nyíldiagrammal (a kapcsolatok két leggyakrabban használt reprezentációs módjával). A „Számok” feladattal kapcsolatosan megjegyezzük, hogy ekkor az is okozhatta a problémát, hogy a tanulóknak szokatlan volt az ilyen típusú kapcsolat, vagyis amikor felosztott alaphalmazzal kell dolgozni. 
Sikeresebben adták még a két halmazt, illetve a kapcsolat más, releváns reprezentációját a „Füzetek” és a „Hónapok” feladatkártyák esetében, amikor is a halmazoknak véges számú elemei voltak (2. ábra). (Megjegyezzük, hogy a „Hónapok” esetében az A halmaz leszűkítését használták.). Valószínűleg az ilyen típusú kapcsolatok ismertebbek voltak számukra.
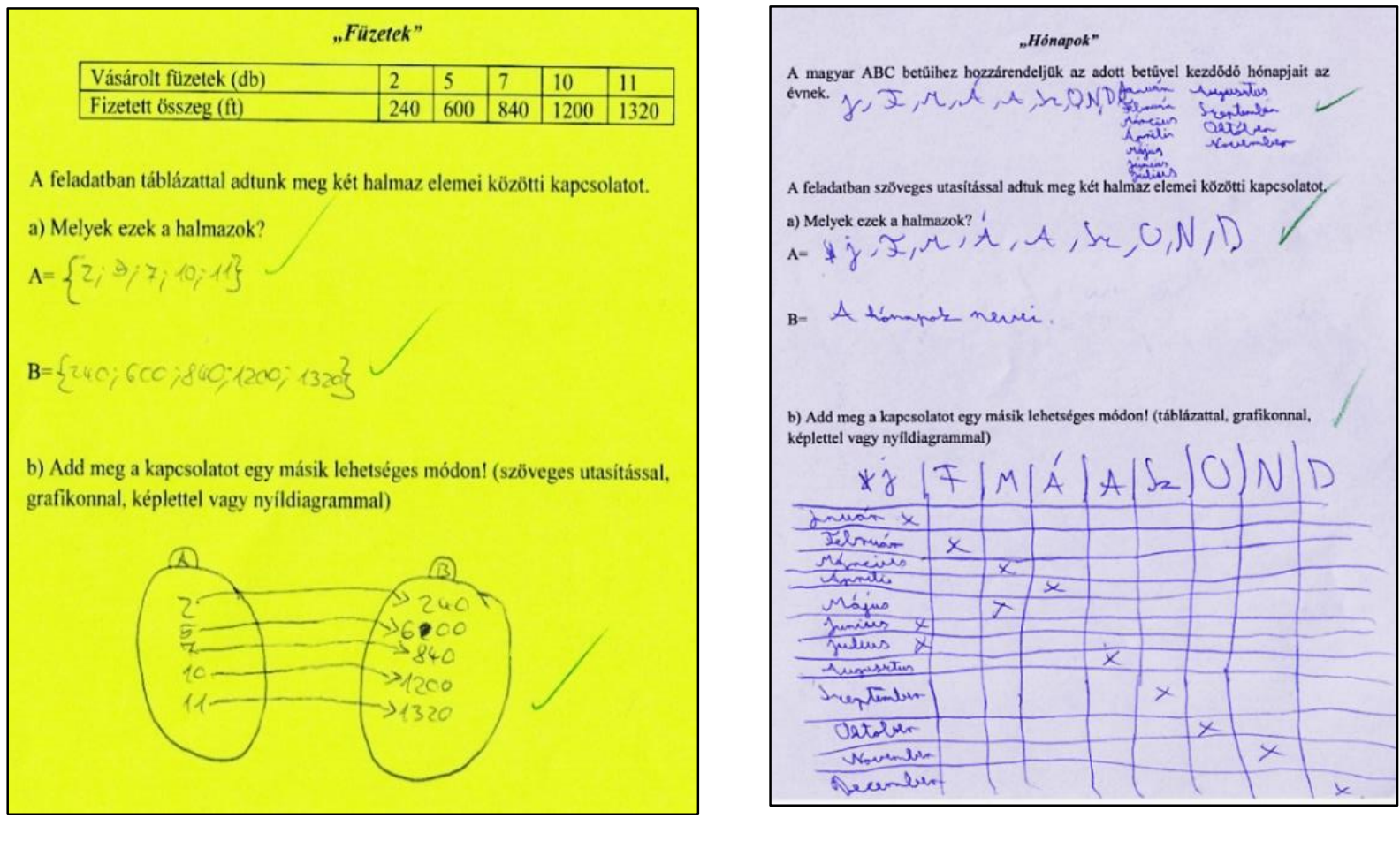

2. ábra

\subsubsection{A tanulók függvényfogalmi-képzetének vizsgálata és alakítása}

A foglalkozás első részében tapasztalt hibák javítása előtt a tanulók függvényről kialakult képzetét vizsgáltuk meg. Az egyes csoportok azt a feladatot kapták, hogy a náluk lévő kapcsolatokról döntsék el, hogy függvénykapcsolatok-e és írják le érvelésüket is. Miután a csoportok elkészültek a csoport 1-1 képviselője a tábla megfelelő helyére („Függvény”, „Nem függvény”) kiragasztották a náluk lévő kapcsolatot és elmondták érvelésüket is. Eközben a többi csoportnak kivetítésre került a tárgyalt kapcsolat.

Annak ellenére, hogy a „Hónapok” és a „Számok” nem függvénykapcsolatok szerepeltek, mind a 4 csoport úgy gondolta, hogy a náluk lévő kapcsolat függvénykapcsolat (3. ábra).

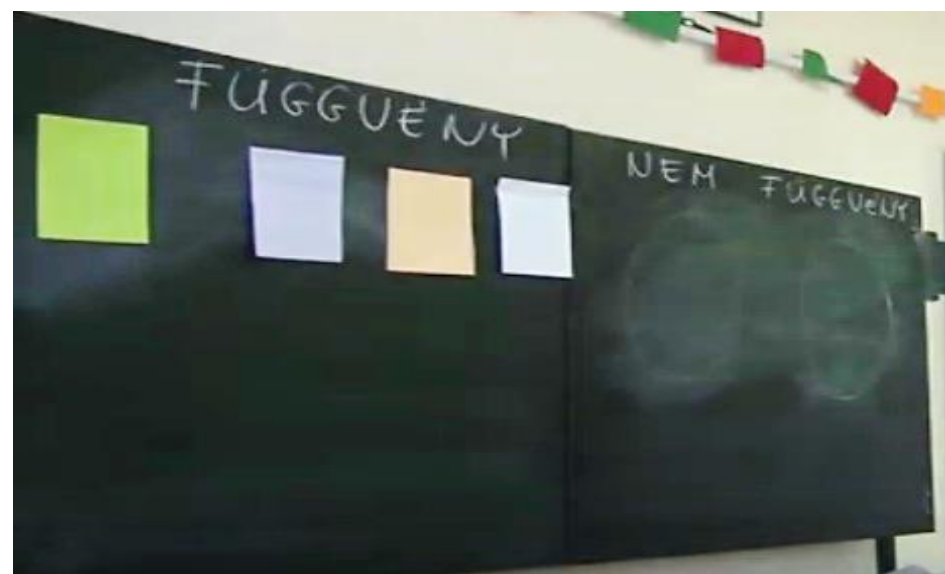


Az egyes csoportok képviselői elmondták a csoportjukkal közösen meghozott érvelést és csak azután javították a hibákat, miután minden kapcsolat esetében elhangoztak az érvelések.

Tanulói érvelések:

1. „Füzetek” kapcsolat: „Függvény, mert az egyes elemeket a másik halmazban lévő elemekhez tudjuk kapcsolni. Többféleképpen lehet ábrázolni és ez a függvények tulajdonsága."

2. „Hónapok” kapcsolat: „Függvény, mert hozzá lehet rendelni egymáshoz a két halmazt. Tehát van köztük kapcsolat."

3. „Mozgás” kapcsolat: „Függvény, mert a megtett út függ az idôtől, és egy részéhez csak egy dolgot tudunk hozzátenni."

4. „Számok” kapcsolat: „Függvény, mivel kiszámolás után pontosan meg tudjuk adni az A és a $B$ halmaz elemeit."

Kiemelendő, hogy a valós folyamatot leíró függvény („Mozgás” feladat) esetében az érvelésnél a gyakorlati tapasztalatra támaszkodtak és a „függvény” szó hétköznapi jelentésére alapoztak.

Ezután sorra vettük az egyes kapcsolatokat és osztálytermi megbeszélés során elemeztük őket (a kapcsolatok egyenként kivetítésre kerültek). A „Hónapok” esetében az egyik csoporttól jött egy fontos érvelés amellett, hogy ez a kapcsolat nem függvény: „nem minden betűhöz tartozik hónap”. Itt a tanuló a függvénydefiníció egy fontos részére utalt: az alaphalmaz minden eleméhez rendelünk a képhalmazból. Ezután tanári rávezetéssel jöttek rá, hogy van olyan betű, amihez többet is rendeltünk, tehát ez a hozzárendelés nem egyértelmü.

A „Számok” kártyával többet időztünk, annak nehezen történő értelmezése miatt: a tanulók munkájából kitűnt, hogy a felosztott alaphalmazt tekintették azon két halmaznak, melynek elemei között kapcsolatot teremtettünk.

Az érvelésekből kitűnt, hogy a képzetükben a függvény kapcsolatot, hozzárendelést jelent ugyan, amit többféle módon lehet reprezentálni, de azon legfontosabb tulajdonsága, hogy annak egyértelmű hozzárendelésnek kell lennie, a tanulók többségénél nem volt mérvadó.

Minden egyes kapcsolat megvitatása után megbeszéltük azt is, hogy a csoport hogyan reprezentálta más módon még a kapcsolatot, az helyes volt-e, illetve hogyan lehet másképpen is reprezentálni még. A két legnépszerűbb reprezentációs mód a táblázat és a nyíldiagram volt. A tanulóknál itt érezhető volt a bizonytalanság, hogy pl. a „Mozgás” feladatnál miért nem lehetett táblázattal megadni a kapcsolatot (ők csak 0-tól 4-ig a pozitív egész számokat írták az alaphalmazba és 0-tól 200-ig a képhalmazba is. (Az egyes kapcsolatok más lehetséges reprezentációs módjaival együtt kivetítettük.)

Ezután arra is kitértünk, hogy a „Füzetek” esetében a grafikon pontjait miért nem lehetett összekötni, míg a „Mozgás” esetében viszont igen. Ekkor helyes érvelés hangzott el: „...mert az alaphalmazban csak pozitív egész számok vannak a füzetek esetében".

A függvény definíciójának, az értelmezési tartomány, a képhalmaz és az értékkészlet fogalmainak tisztázása után a tanulókat arra kértük, hogy a kiosztott "Füzetek”, "Mozgás” feladatkártyákon szereplő 
függvényeknek adják meg az értelmezési tartományát, a képhalmazát, valamint az értékkészletét. Néhány percig egyénileg dolgoztak, majd elmondták a válaszaikat, amit közös megbeszéléssel először szóban, majd írásban korrigáltunk. Az alábbi ábrán jól látható, hogy a tanulók válaszaikat a megbeszélés után javították (4. ábra).

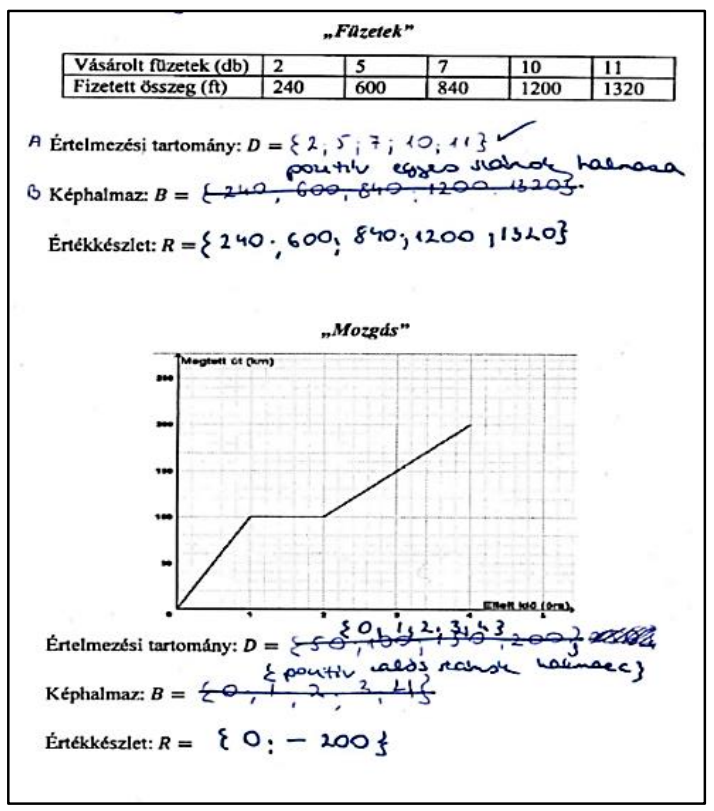

4. ábra

A korrigálás jól mutatja, hogy az értelmezési tartomány pontos megadása, illetve a képhalmaz és az értékkészlet azonosítása nehézségekbe ütközött.

Ezt követően a függvény grafikonjának definíciójával foglalkoztunk külön kitérve arra, hogy mikor reprezentálható egy függvény grafikonnal.

\subsection{3. „Számpár-számpár” típusú kapcsolat vizsgálata}

Annak érdekében, hogy a függvényfogalomhoz ne csak „szám-szám” típusú hozzárendelés társuljon, derékszögű koordináta-rendszerben 5 pontot ábrázoltunk és a tanulóknak meg kellett keresni azok tükörképeit, majd választ adni a feladatlapon feltüntetett kérdésekre (5. ábra).

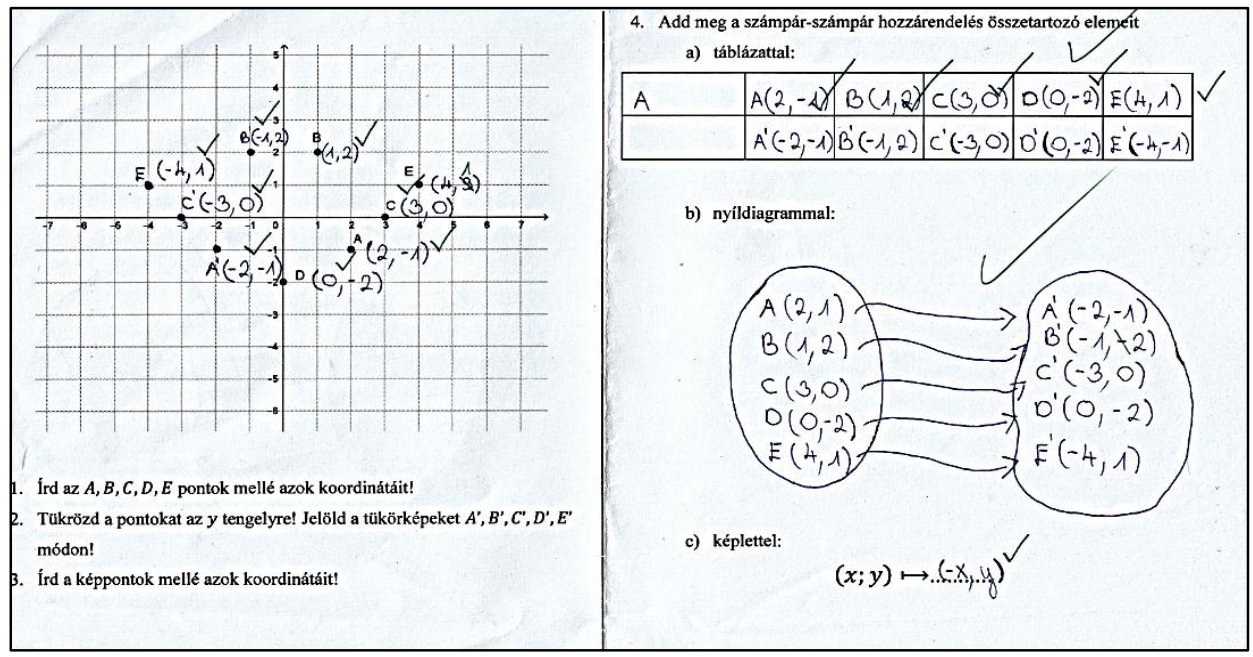


5. ábra

Az órán elhangzottak alapján ezt a feladatot már sikeresebben oldották meg a tanulók. A sikeres feladatmegoldásban úgy véljük az is szerepet játszott, hogy a geometriai transzformációkban a tanulók könnyebben meglátták a függvény operatív értelmezését („input-transzformáció-output”). Emiatt is javasolja a függvényfogalomnak az alakítását geometriai függvényekkel Scott Steketee (2012). Véleménye szerint a fogalom konkrét geometriai transzformációkkal való bevezetése, majd alakítása célravezető lenne: a geometriai függvények (geometriai transzformációi a pontoknak a síkban - ponthoz pontot rendelő függvény) és a hozzájuk kapcsolódó reprezentációk segíthetik a tanulókat az intuitív megértésben, a tévképzetek elkerülésében és a változók, függvények mélyebb megértésében.

\section{3. Összegzés}

A tanulmányban bemutatott foglalkozás célja a korábban tanult függvényfogalomnak - mely nagyon fontos szerepet játszik a műszaki életben - a felelevenítése és alakítása volt különböző kapcsolatok vizsgálatával kooperatív tanítási/tanulási módszer segítségével. A foglalkozás során szerzett tapasztalatokat a kutatási kérdések alapján összegezzük:

1. Képesek-e a 9. osztályos tanulók a kapcsolatot megadó egyik reprezentációs módról áttérni egy másik, releváns reprezentációs módra, és leginkább melyik lehetséges reprezentációs módot preferálják a tanulók?

A vizsgált tanulók abban az esetben, amikor a kapcsolat értelmezési tartománya a valós számok halmaza vagy annak valamely részhalmaza nehezen ismerték fel annak egy másik, releváns reprezentációs módját. A legtöbben a táblázat és a nyíldiagram reprezentációkat helyezték előtérbe, nem véletlenül, hiszen a fogalom bevezetésénél, illetve például annak grafikonnal történő megadásánál ezek a reprezentációs módok épülnek be leginkább a tanítási-tanulási folyamatba.

2. Mi jellemzi az adott korosztályban a tanulók függvényfogalom-képzetét?

Az adott csoportnak 9. osztályban láthatóan hibás fogalomképzete volt a függvényről. A tanulóknak nehezen bár, de sikerült induktív úton felfedezniük a különböző kapcsolatokban a függvény fogalmát (amit 7. és 8. osztályban már tanulták): azt, hogy az egy speciális reláció (hozzárendelés), továbbá, hogy a definiáló tulajdonságok hogyan jelennek meg a különböző reprezentációs módokban. Jól érzékelhető volt, hogy érvelésük azon alapult, hogy kapcsolatot létesítettünk két halmaz elemei között, de a legfontosabb definiáló tulajdonságtól eltekintettek. Egy másik jellemző érvelés a függvény megértésének „Cselekvés” (Sierpinska, 1992) szakaszára utalt: a tanulók a függvényt olyan „valamiként” képzelik el, mely megadja egy kifejezés értékét a változó egy bizonyos értéke mellett.

Ezért mindenképpen szükségesnek látjuk a függvényfogalom iskolai alakítási folyamatába való „beavatkozást” a fogalomalakítást megcélzó foglalkozások tervezésével és megvalósításával a fogalom bevezetését és azt követő évfolyamokon is. A fogalom alakításával egyidőben a gyerekek olyan képessége is fejleszthető, amelyet egy leendő mérnöknek is birtokolni kell: a valós folyamatokban a 
különböző halmazok és az azok közötti kapcsolatok felismerésének, valamint többféle módon történő megadásának képessége.

\section{Köszönetnyilvánítás}

A publikáció elkészítését az EFOP-3.6.1-16-2016-00022 számú projekt támogatta. A projekt az Európai Unió támogatásával, az Európai Szociális Alap társfinanszírozásával valósult meg.

A tanulmány elkészítését részben a Magyar Tudományos Akadémia Tantárgypedagógiai Kutatási Programja támogatta.

\section{Hivatkozások}

[1] Á. Tuke, O. Oppe, G. Dávid, Oktatás-módszertani füzetek. PTE Bölcsészettudományi Kar Politikai Tanulmányok Tanszék, 2011.

[2] Ambrus, A., Bevezetés a matematikadidaktikába. Eötvös Kiadó, revised, 2004.

[3] Areti P., Paraskevi M., Andreas P., Teaching the concept of function: Definition and problem solving. Konrad Krainer; Nada Vondrova. CERME 9 - Ninth Congress of the European Society for Research in Mathematics Education, Feb 2015, Prague, Czech Republic. pp.440-445, Proceedings of the Ninth Congress of the European Society for Research in Mathematics Education.

[4] Clement, L., What do students really know about functions? Mathematics Teacher, 94(9), 745748., 2001.

[5] Dienes, Z., Építsük fel a matematikát. Edge 2000 Kiadó, 2015.

[6] Dubinsky, E. \& Harel, G., The nature of the process conception of function. In G. Harel and E. Dubinsky (eds.), The concept of function: aspects of epistemology and pedagogy (pp. 85-106). DC: Mathematical Association of America, 1992.

[7] Duval, R., Representation, vision and visualization: Cognitive functions in mathematical thinking. Basic issues for learning. In Proceedings of the 21st North American Chapter of the International Group for the Psychology of Mathematics Education, Morelos, Mexico, 3-26, 1999.

[8] Sajka, M., A secondary school student's understanding of the concept of function - A case study. Educational Studies in Mathematics, 53, 229-254, 2003.

[9] Scott N. Steketee (2012). Using Technology to Integrate Geometry and Algebra in the Study of Functions. In Sung Je Cho (Ed.), The Proceedings of the 12th International Congress on Mathematical Education, pp. 617-620. 
[10] Selden, A. \& Selden, J., Research Perspectives on Conceptions of Functions: Summary and Overview. In Harel, G. \& Dubinsky, E. (eds.) The Concept of Function. Aspects of Epistemology and Pedagogy. Mathematical Association of America, 1-16., 1992.

[11] Sfard, A., On the dual nature of mathematical conceptions: reflections on processes and objects as different sides of the same coin, Educational Studies in Mathematics 22, 1-36., 1991.

[12] Sierpinska, A., On understanding the notion of function. In G. Harel \& E. Dubinsky (Eds.), The concept of function: Aspects of epistemology and pedagogy (p. 25-58). Washington: DC: Mathematical Association of America, 1992.

[13] Skemp, R.R., A matematikatanulás pszihológiája (S. Klein, ford.). Edge 2000 Kiadó, Budapest, 2005. (Eredeti könyv publikálva1971-ben.)

[14] Szanyi, Gy., Általános iskolás tanulók és egyetemi hallgatók fogalomképzetei a függvényről. INTERNATIONAL JOURNAL OF ENGINEERING AND MANAGEMENT SCIENCES / MÜSZAKI ÉS MENEDZSMENT TUDOMÁNYI KÖZLEMÉNYEK 2:(2), 14-122, 2017b.

[15] Szanyi, Gy., Fogalomképzetek és definíciók a függvényről. In Imre Kocsis (ed.), Proceedings of the Conference on Problem-based Learning in Engineering Education (pp. 36-41). Debrecen, 2015.

[16] Thompson, P.W., Students, functions, and the undergraduate curriculum. In Dubinsky, E., Schoenfeld, A., Kaput, J. (eds.), Research in Collegiate Mathematics Education, I, CBMS Issues in Mathematics Education, Vol. 4, 21-44, 1994.

[17] Vinner, S. \& Dreyfus, T., Images and definitions for the concept of function. Journal for Research in Mathematics Education, 20(4), 356-366., 1989.

[18] Vinner, S., Concept definition, concept image and the notion of function. International Journal of Mathematical Education in Science and Technology, 14, 293-305., 1983. 